5000 separate memoirs have been examined page by page. The substances are arranged in alphabetical order, and are also indexed according to formulæ. The references are indicated by numbers which correspond to the index of authors given at the end of the volume.

The book is well printed on good paper, and is solidly bound in cloth. It is the only complete work on the subject, and will be a valuable addition to English standard books of reference.

J. B. C.

\section{UUR BOOKSHELF.}

Boilers, Economisers, and Superheaters: Their Heating Power and Efficiency. By Prof. R. H. Smith. Pp. viii + I28. (London : Crosby. Lockwood and Son, I9I5.) Price $7 s$. 6d. net.

THE author's purpose in this book is to provide material whereby the designer of steam boilers may take account of the transmission of heat by radiation from the incandescent fuel and the incandescent parts of the flame in as full and scientific a manner as the data at present available makes possible. It is assumed that combustion is completed within, or close to the surface, of the mass of coal, and that the heat so produced is divided between heating the solid coal and heating the generated gases. This assumption enables the furnace gas temperature to be calculated for various ratios of air actually admitted to the furnace to the air required by chemical theory, and for various heating values of the fuel. The result indicates that the temperature depends almost solely upon the air ratio, and to a minute degree only upon the heating value of the coal. The heat given up by the gases passing along the flues is then dealt with and similar calculations are given for economisers; applications to superheaters form the subject of a separate chapter. The laws of heat transmission in boilers are too complex for ready use in engineering drawing offices, and the author has reduced these laws to the form of diagrams. It is unfortunate that these diagrams, while showing the way in which the quantities involved vary, are reproduced to a scale too small to be read accurately; the reader interested in boiler design is invited to purchase copies of the original large-scale diagrams. There is a great deal of interesting and useful matter in the book, but it is not presented in a very readable form, and the practical designer is likely to consult the diagrams much more frequently than he will refer to the text.

Through the Grand Canyon from Wyoming to Mexico. By E. L. Kolb. Pp. xix +344 . (New York : The Macmillan Co; London: Macmillan and Co., Ltd., I9I4.) Price $8 s .6 d$. net.

THis is a graphic but unassuming account of one of the very few successful descents through the country of the Grand Canyon by boat from end to end. For European readers it should have contained a map, to ensure the appreciation of the NO. $236 \mathrm{I}$, VOL. 947 vast distances involved and the remoteness from civilisation of the plateau-heights on either hand. Anyone who has travelled along gorges, such as the Bosnian canyon of the Vrbas, will realise the effect of a sudden contact with the outer world, where some trail descends by a gentler part of the valley-side, finds a passage across the river, and climbs again to the upper air. Such episodes, leading to the visiting of ranches where pioneers and outlaws still lead unhampered lives, broke the long series of hazards which the fearless author and his brother set before themselves. No two of the cataracts are alike, and the tale is so well told that the reader feels himself limited by rock-walls $4000 \mathrm{ft}$. in height; he sees the huge fallen blocks that seem to bar the passage, the spray rising from some swift descent ahead, the fierceness of which cannot yet be adequately gauged; he feels the whirl of the water round him in the rapids, where the boat twists like a porpoise in green waves; and at the end, among the sand-bars and marshes close to Needles, after a hundred-and-one days of travel, he takes leave of his guides with a genuine and affectionate regret.

The brothers Kolb are professional photographers, as the fine illustrations in this book so amply testify. The famous journey of $\mathrm{J}$. W. Powell in $\mathrm{r} 869$ is, of course, fully acknowledged, and references are given to Stanton, Galloway, Stone, and to the nameless trappers or prospectors who are known to us only by shattered boats or bleaching skeletons in the gorge. The geological study of the district has aptly influenced Mr. Kolb's descriptions, and seldom has a great adventure, carried out with skilled endurance, been told so simply and with so fine an absence of self-regard.

Grenville A. J. Cole.

Pumping by Compressed Air. By E. M. Ivens. Pp. vi +244 . (New York: J. Wiley and Sons, Inc. ; London : Chapman and Hall, Ltd., r9r4.) Price I2s. $6 d$. net.

IN compiling this book the author has had the advantage of being able to draw on considerable practical experience derived from installing and testing air lifts operating under a wide range of conditions. Very good and clear descriptions are given of various types of displacement pumps, return air systems, air lifts, and pumping systems generally. Of particular interest are the sections dealing with the air lift. In this system a long vertical pipe is led down the well, and has an open mouth near the bottom and under the waterlevel, so that normally the water stands at a considerable height inside the pipe. Compressed air is led down the well by a separate pipe, and is discharged through suitably shaped orifices into the first-mentioned pipe at a point well below normal water-level. The ascending bubbles of air cause an upward flow of water, which is finally discharged into a tank at or above ground-level. The theories of Harris and of Lorenz regarding the action in air lifts will be found in the book, together with much matter of practical interest. The practical treatment is good, and forms a 